\title{
INVENTORY OF WILD RODENTS AND LAGOMORPHS AS NATURAL HOSTS OF FASCIOLA HEPATICA ON A FARM LOCATED IN A HUMID AREA in Loire Atlantique (France)
}

\author{
MÉNARD A.*, L'HOSTIS M.*, LERAY G.**, MARCHANDEAU S.**, PASCAL M.***, ROUDOT N.*, \\ MICHEL V.**** \& CHAUVIN A.*
}

\section{Summary :}

With the objective of studying the role of wild fauna in the epidemiology of fasciolosis disease, a definitive wild-host inventory was carried out in a french farm where infected domestic hosts (cows) cohabit with wild potential ones. Liver flukes, faecal eggs and antibodies were looked for in lagomorphs (Oryctolagus cuniculus) and rodents (Myocastor coypus, Ondatra zybethicus, Rattus norvegicus, Arvicola sapidus and micromammal species) trapped in the study area. Presence of Fasciola hepatica was detected in two species: $O$. cuniculus and $M$. coypus. Infection rates were respectively $34 \%(42 / 124)$ and $55 \%$ (106/193). Liver flukes were found in $78 \mathrm{M}$. coypus ( $\mathrm{n}=192)$ and 110 . cuniculus $(n=35)$. No other species was infected by $F$. hepatica. The number of animals shedding fluke eggs was higher in M. coypus (49 out of 127 sampled; $38.6 \%$ ) than in 0 . cuniculus (two out of 17 sampled; $11.7 \%$ ). The results indicate that $M$. coypus may play a role in the maintenance and the dissemination of $F$. hepatica in various environments and open a discussion on the role of other natural wild hosts.

KEY WORDS : epidemiology, Fasciola hepatica, Loire Atlantique, Myocastor coypus, Oryctolagus cuniculus, rodents, wild fauna.
Résumé : INVENTAIRE DES PETITS MAMMIFÈRES SAUVAGES HÔTES NATURELS DE FASCIOLA HEPATTCA DANS UNE EXPLOITATION AGRICOLE SITUÉE DANS UNE ZONE HUMIDE DE LOIRE ATLANTIQUE

Afin d'étudier le rôle de la faune sauvage dans l'épidémiologie de la fasciolose, un inventaire des rongeurs et des lagomorphes hôtes sauvages de Fasciola hepatica a été effectué dans une ferme française où des bovins infestés cohabitent avec des animaux sauvages potentiellement hôtes. La présence de douves hépatiques, d'œuts dans les fèces et d'anticorps sanguins a été recherché chez des lagomorphes (Oryctolagus cuniculus) et des rongeurs (Myocastor coypus, Ondatra zybethicus, Rattus norvegicus, Arvicola sapidus et micromammifères) capturés sur la zone d'étude. La présence de Fasciola hepatica a été observée chez deux espèces: $O$. cuniculus et $M$. coypus. Les taux d'infestation sont respectivement de $34 \%(42 / 124)$ et $55 \%$ (106/193). Des douves ont été isolées dans 78 foies de $M$. coypus ( $n=192$ ) et 11 foies de $O$. cuniculus ( $n=35)$. Aucune autre espèce n'est infestée. Le nombre d'animaux infestés excréteurs d'œuts est plus élevé chez $M$. coypus 149 sur les 127 échantillonnés; $38,6 \%$ ) que chez $O$. cuniculus $(2$ sur les 17 échantillonnées; 11,7\%). Les résultats témoignent du rôle possible de M. coypus dans le maintien et la dissémination de F. hepatica et permettent de discuter du rôle des autres hôtes sauvages.

MOTS CLÉS : épidémiologie, Fasciola hepatica, faune sauvage, Loire Atlantique Myocastor coypus, Oryctolagus cuniculus, rongeurs.

\section{INTRODUCTION}

$F$ Tasciola bepatica is an euryxene parasite found in many domestic species [bovines, ovines, [ caprines (Reddington et al., 1986)] and wild species like rodents (Delecole, 1982; Molan \& Hussein, 1988; Mas-Coma et al., 1988 and 1989), lagomorphs (Bailenger et al, 1965; Terracciano et al., 1988), suidae (Bollo et al., 1993) and wild ruminants

\footnotetext{
* UMR ENVN/INRA "Interactions Hôte-Parasite-Milieu", École Nationale Vétérinaire de Nantes, BP 40706, 44307 Nantes, France.

** Office National de la Chasse, 53, rue Russeil, 44000 Nantes, France.

*** Département hydrobiologique et faune sauvage, Université Rennes I, 35042 Rennes Cedex, France.

${ }^{* * * *}$ Laboratoire de pathologie infectieuse, École Nationale Vétérinaire de Nantes, BP 40706, 44307 - Nantes, France.

Correspondence: Alexandre Ménard.

Tél. : 33 (0)2 40687700 - Fax : 33 (0)2 40687751.
}

(Barras,1982; Johannsen et al., 1989; Alcouffe et al., 1992), and even in Man. The economic consequences of domestic ruminant infestation (Mage et al., 1989; Mage, 1990) and the increase of the number of human contaminations worldwide (Mas-Coma et al., 1999) warrant an effective control of fasciolosis. The use of fasciolicide molecules is recommended to stop the laying of adult parasites present in cattle. The existence of infested wild animals can be a limit to this strategy by allowing the pursuit of the parasitic life cycle and the reinfestation of sympatric potential hosts like domestic animals or man. Dreyfuss et al., in 1994, demonstrated human contaminations in watercress beds located in plots outside of cattle presence but where the presence of wild rodents and lagomorphs was reported. To establish the real impact of wild fauna in fasciolosis epidemiology, it is important to know which species are susceptible to the parasite and which ones have a more durable relationship with it. 
The aim of this study is to list the wild small mammals species infested by $F$. hepatica on a small scale in France, where wild and domestic animals live in sympatry, and to discuss the nature of the relationships established between these species and $F$. bepatica to consider their role in the parasite's maintenance and dissemination.

\section{MATERIALS AND METHODS}

\section{DESCRIPTION OF THE STUDY AREA} AND COW-BREEDING

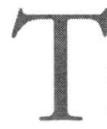
The study was carried out on the Massereau reserve (Loire Atlantique, France) managed by the National Hunting Office (Office National de la Chasse; ONC), from 1995 to 1998. The total surface of the reserve is 393 hectares ( 982.5 acres). A study area of 45 hectares (112.5 acres) was defined (area 1, Fig. 1). A second area of 19 hectares ( 47.5 acres), ecologically similar to the first, had to be defined to increase the size of our samples (area 2, Fig. 1). Each of these two areas consisted of three ecologically different environments: damp meadows (environment 1) surrounded below by slimy calcareaous borders (environment 2 )

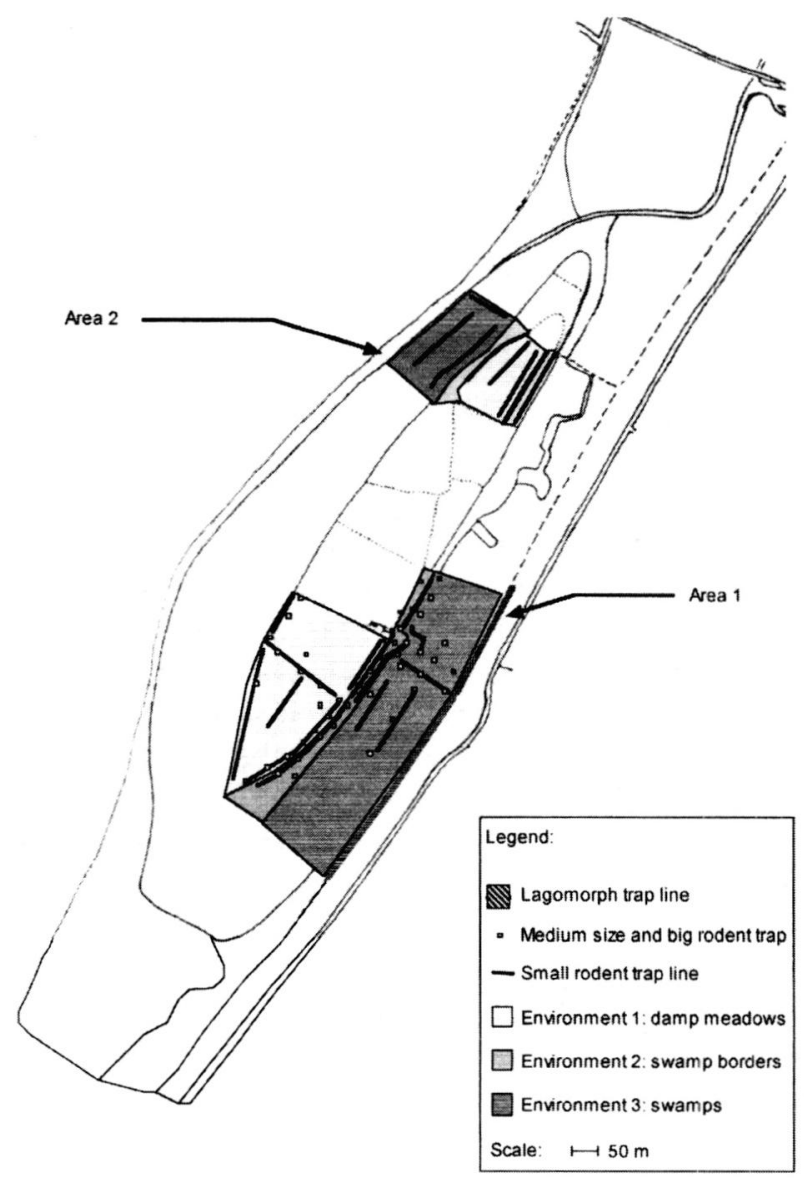

Fig. 1. - Study area topography. one part of which is flooded during the floods of the river (la Loire) (environment 3). These three environments are potential Lymnaea truncatula habitats.

The results will be dealt with depending on the three environments and not on the areas.

Eighteen cows (Nantaise breed) grazed in area 1. Cattle were treated yearly with triclabendazole (Fascinex ND). The serological infection rate of cattle was measured by ELISA method to $90 \%(n=12)$ (Boulard et al., 1995).

Foot print observation proved the presence of wild animals sympatric with cows.

\section{SAMPLING OF THE WILD SPECIES}

A total of 250 traps of INRA and Sherman traps and rat-trap-Manufrance-for-capture-of-small-rodents types were set every three months, according to the method described by Spitz (1965), in the three area 1 environments from November 1996 to November 1997, and in the three area 2 environments, in November 1996 and July 1997 (Fig. 1). Trappings using rat-trap-Manufrancefor-capture-of-small-rodents were pursued in the third environment of the area 1 until november 1999, at the same periodicity. Thirty traps for the capture of medium size and big rodents were set every three months from November 1996 to July 1998, and divided out among the three area 1 environments (Fig. 1).

All the animals captured were euthanasied.

A line of 55 rabbit traps were set in part of area 1 with the highest concentration of rabbits (Oryctolagus cuniculus), from November 1996 to March 1998. A study carried out by ONC necessitated the release of the Oryctolagus cuniculus trapped. To demonstrate the fluke carrying by O. cuniculus, O. cuniculus shooting were also carried out by ONC, in the same place. The carcasses were collected monthly.

\section{INFECTION DIAGNOSIS IN THE SAMPLED SPECIES}

Table I summarizes the four methods of infestation diagnosis used for each species.

The animal autopsies included a meticulous exploration of the choledoc canal and biliary ducts followed by a fine cut of the liver.

Bile was extracted after puncturing the gall bladder. The bile was observed to look for fluke eggs.

The coproscopic diagnosis was carried out using a iodomercurate potassium flotation method (Knapp \& Presidente, 1971).

Serological infestation was established using an ELISA method (Boulard, 1995), adapted for each species.

\section{STATISTICS}

The mean values were subjected to Anova or to the comparison test of experimental frequencies. 


\begin{tabular}{|c|c|c|c|c|c|c|c|c|c|c|}
\hline & \multirow[b]{2}{*}{ Captures } & \multirow[b]{2}{*}{$\begin{array}{l}\text { Infected } \\
\text { animals }\end{array}$} & \multicolumn{2}{|c|}{ Autopsy } & \multicolumn{2}{|c|}{ Blie examination } & \multicolumn{2}{|c|}{ Coproscopy } & \multicolumn{2}{|c|}{ Serology } \\
\hline & & & Realized & $\begin{array}{c}\text { Adult } \\
\text { worms }\end{array}$ & Realized & $\begin{array}{l}\text { Bile } \\
\text { eggs }\end{array}$ & Realized & $\begin{array}{l}\text { Faecal } \\
\text { eggs }\end{array}$ & Realized & Positives \\
\hline C. capreolus & 3 & 2 & 0 & 0 & 0 & 0 & 2 & 2 & 3 & 2 \\
\hline O. cuniculus & 124 & 42 & 35 & 11 & 27 & 10 & 17 & 2 & 68 & 33 \\
\hline M. coypus & 193 & 106 & 192 & 78 & 179 & 88 & 127 & 49 & 167 & 133 \\
\hline O. zybetbicus & 22 & 2 & 22 & 0 & 13 & 0 & 14 & 2 & 0 & 0 \\
\hline R. norvegicus & $65(32+33)^{*}$ & 0 & $65(32+33)^{*}$ & 0 & 0 & 0 & 0 & 0 & $35(15+20)^{*}$ & 0 \\
\hline A. sapidus & 1 & 0 & 1 & 0 & 1 & 0 & 0 & 0 & 0 & 0 \\
\hline A. sylvaticus & 361 & 0 & 361 & 0 & 0 & 0 & 0 & 0 & 0 & 0 \\
\hline M. arvalis & 89 & 0 & 89 & 0 & 0 & 0 & 0 & 0 & 0 & 0 \\
\hline$M$. agrestis & 4 & 0 & 4 & 0 & 0 & 0 & 0 & 0 & 0 & 0 \\
\hline C. glareolus & 16 & 0 & 16 & 0 & 0 & 0 & 0 & 0 & 0 & 0 \\
\hline
\end{tabular}

* Total of the Rattus norvegicus captured (number of Rattus norvegicus captured between november 1997 and november $1998+$ number of Rattus norvegicus captured between november 1998 and november 1999).

Table I. - Number of infected animals depending on the species and the screening method.

\begin{tabular}{|c|c|c|c|c|c|c|c|c|c|c|c|c|c|c|c|c|c|c|c|c|c|c|}
\hline & \multicolumn{8}{|c|}{ O. cuniculus } & \multicolumn{8}{|c|}{ M. coypus } & \multicolumn{6}{|c|}{ O. zybeticus } \\
\hline & \multirow[t]{2}{*}{ Captures } & \multicolumn{2}{|c|}{ A } & \multicolumn{2}{|c|}{ B } & \multicolumn{2}{|c|}{$\mathrm{C}$} & $\mathrm{S}$ & \multirow[t]{2}{*}{ Captures } & \multicolumn{2}{|c|}{ A } & B & \multicolumn{2}{|c|}{$\mathrm{C}$} & \multicolumn{2}{|c|}{ S } & \multirow[t]{2}{*}{ Captures } & \multicolumn{2}{|c|}{ A } & \multicolumn{2}{|c|}{ B } & $\mathrm{C}$ \\
\hline & & $\mathrm{N}$ & $\%$ & $\mathrm{~N}$ & $\%$ & $\mathrm{~N}$ & $\%$ & $\mathrm{~N} \%$ & & $\mathrm{~N}$ & $\%$ & $\mathrm{~N} \quad \%$ & $\mathrm{~N}$ & $\%$ & $\mathrm{~N}$ & $\%$ & & $\mathrm{~N}$ & $\%$ & $\mathrm{~N}$ & $\%$ & $\mathrm{~N} \%$ \\
\hline \multirow{2}{*}{$\begin{array}{l}\text { Humid meadows } \\
\text { environment } 1\end{array}$} & 2 & 2 & 0 & 2 & 0 & 2 & 0 & 1100 & 48 & 47 & 15 & $42 \quad 24$ & 37 & 16 & 46 & 30 & 8 & 8 & 0 & 7 & 0 & 50 \\
\hline & & $\mathrm{N}$ & $\%$ & $\mathrm{~N}$ & $\%$ & $\mathrm{~N}$ & $\%$ & $\mathrm{~N} \%$ & & $\mathrm{~N}$ & $\%$ & $\mathrm{~N} \quad \%$ & $\mathrm{~N}$ & $\%$ & $\mathrm{~N}$ & $\%$ & & $\mathrm{~N}$ & $\%$ & $\mathrm{~N}$ & $\%$ & $\mathrm{~N} \%$ \\
\hline \multirow{2}{*}{$\begin{array}{l}\text { Swamps border } \\
\text { environment } 2\end{array}$} & 122 & 32 & 34 & 25 & 37 & 15 & 13 & 6748 & 69 & 69 & 41 & 6248 & 43 & 42 & 45 & 49 & 3 & 3 & 0 & 2 & 0 & 20 \\
\hline & & $\mathrm{N}$ & $\%$ & $\mathrm{~N}$ & $\%$ & $\mathrm{~N}$ & $\%$ & $\mathrm{~N} \%$ & & $\mathrm{~N}$ & $\%$ & N \% & $\mathrm{N}$ & $\%$ & $\mathrm{~N}$ & $\%$ & & $\mathrm{~N}$ & $\%$ & $\mathrm{~N}$ & $\%$ & $\mathrm{~N} \%$ \\
\hline $\begin{array}{c}\text { Swamps } \\
\text { environment } 3\end{array}$ & 0 & 0 & 0 & 0 & 0 & 0 & 0 & 0 & 76 & 76 & 56 & $48 \quad 64$ & 47 & 53 & 43 & 72 & 11 & & 0 & 4 & 0 & $\begin{array}{ll}7 & 29\end{array}$ \\
\hline
\end{tabular}

$\mathrm{A}=$ autopsy; $\mathrm{B}=$ bile observation; $\mathrm{C}=$ coproscopic screening; $\mathrm{S}=$ serology; $\mathrm{N}=$ sample size

Table II. - F. hepatica infection rate depending on the species, the screening methods and the environments.

\section{RESULTS}

\section{EVALUATION OF THE CAPTURES}

T Table I gives the number of trapped animals per species. Nine species were sampled in the study areas: four aquatic rodent species, four micromammal rodent species and one lagomorph species. Four species were captured more often: 361 Apodemus sylvaticus, 193 Myocastor coypus, 124 Oryctolagus cuniculus and 89 Microtus arvalis.

Table II gives the repartition of the captures based on the environment. The number of trapped $M$. coypus was not significantly different in the three environments (39 \% of $M$. coypus trapped were captured in environment $1,36 \%$ in environment $2,25 \%$ in environment 3). The results were the same for O. zybethicus (36.4\% of O. zybethicus trapped were captured in environment $1,13.6 \%$ in environment 2 and $50 \%$ in environment 3 ). Only two Rattus norvegicus were trapped in the driest biotope (environment 1) (6.2\% out of the $32 R$. norvegicus trapped among the three environments) against $40.6 \%$ in environment 2 and $53.2 \%$ in environment 3 . On the contrary, micromammals were trapped more frequently in dry biotopes: $56.4 \%$ in the environment 1 and $42.6 \%$ in environment 2 against $1 \%$ in environment 3 . The trapping and the shooting of O. cuniculus were carried out in only one environment.

\section{DIAGNOSIS OF FLUKE INFECTION}

The results of the infection diagnosis per species are summarized in Table I. We observe two species for which all the screening methods used show fluke infection: M. coypus and O. cuniculus. In these two species, fluke stages were detected [liver flukes in $78 \mathrm{M}$. coypus $(\mathrm{n}=192)$ and 11 O. cuniculus $(\mathrm{n}=35)$; faecal eggs in $49 M$. coypus $(\mathrm{n}=127)$ and two O. cuniculus $(\mathrm{n}=17)]$ and antibodies were observed in blood samples [133 M. coypus $(\mathrm{n}=167)$ and 33 O. cuniculus $(\mathrm{n}=68)]$. 
The infection rates measured (all screening methods combined) in these species are $55 \%$ in $M$. coypus and $34 \%$ in O. cuniculus. The difference is not significant. On the contrary, the frequency of faecal egg shedding was significantly higher $(\mathrm{p}<0.001)$ in $M$. coypus than in O. cuniculus (49/127 and $2 / 2$ respectively instead of $2 / 17$ for O. cuniculus).

In O. zybethicus, the diagnosis were not the same depending on the screening method used: two animals shed faecal eggs but no autopsy revealed fluke livers and no antibodies were detected in blood samples. None of the $65 R$. norvegicus trapped were infested. The ELISA method used in 35 blood samples did not detect any fluke antibodies.

No animal out of the four micromammal species sampled were shown to have fluke livers.

Table II gives infection rates depending on the species and the environment where they were trapped. Infected $M$. coypus were detected in the three environments. The prevalence measured in environment 3 was significantly higher $(\mathrm{p}<0.001)$ than the one measured in environment one $(56 \%$ out of the $76 \mathrm{M}$. coypus trapped in swamps were infected compared to $15 \%$ in humid meadows).

\section{DISCUSSION}

The present sampling of the herbivorous mammals agrees with those carried out by ONC (unpublished data). Only Micromys minutus, whose presence has been reported by ONC, was not trapped in our study. The trapping protocole (exhaustive trapping in area 1 and sampling trapping in area 2) gives a good representation of the potential $F$. hepatica hosts present.

The results confirm the existence of various wild species infected by F. hepatica: lagomorphs (O. cuniculus) and rodents ( $M$. coypus).

O. cuniculus infection has been reported for a long time (Olsen, 1948) and has been observed in several different countries: in France (Bailenger et al., 1965; Hubard, 1985; Biadi \& Le Gall, 1993), in England, USA and Australia (Bailenger et al., 1965), as well as in Rumania (Nesterov et al., 1973), in Czechoslovakia, in Italy and in Chile (Rubilar et al., 1987). The average infection rate measured in our study was in accordance with those reported by the various authors.

In spite of a large potential host spectrum, $F$. hepatica only forms one rodent species ( $M$. coypus).

The positivity of the coproscopic diagnosis in two faecal samples collected in $O$. zybethicus does not prove the infestation of the population. Coproscopic diagnosis is not a specific screening method and it can be difficult to recognize fluke eggs of another endo- parasite eggs (like Alaria spp...). Also, a exogen origin of the faecal eggs cannot be excluded: O. zybethicus is a caecotroph and the quantity of faecal eggs found was low (0.6 and 2.8 eggs per gramme (epg)). The absence of liver flukes and antibodies seems to show that the population sampled is not infested by $F$. hepatica. These results confirm those of Boussinesq who explored, in 1986, the $F$. hepatica susceptibility of a $O$. zybethicus population in area where $M$. coypus infestation was shown. None of the 70 animals autopsied were infested by the parasite. The specific alimentary behavior, which differs strongly from that of M. coypus (Perry, 1982), may provide an explanation for the resistance of $O$. zybethicus to $F$. hepatica.

None $R$. norvegicus nor micromammal species were infected. The absence of $R$. norvegicus and micromammals infected in an infected $F$. bepatica area seems to confirm that parasite carrying is not frequent in these species. $R$. norvegicus infection has only been observed in Irak by Molan \& Hussein (1988) and the prevalence measured was low $(7 \%)$. Only one micromammal infection was detected, in Mus musculus, a species not trapped in our study, by Mas-Coma et al. (1988), in Corsica. Mas-Coma showed that, like the Rattus rattus fluke infection, this phenomenon is the consequence of insularity concerning niche widening in both host and parasite species (Mas-Coma et al., 1989). It appears that the carrying of $F$. hepatica by Rattus spp. and micromammals may only occur under certain circumstances, in particular environments.

$M$. coypus infection is, on the contrary, more widespread. It has been reported in France (Delecole, 1982; Rosoux, 1984; Boussinesq, 1986), in USSR (Zakariev, 1977) and in Brazil, in its native habitat, by Santos et al. (1992). The results show that M. coypus infection occurs in various environments (swamps, humid meadows) and the infection rate can be exceedingly high (serological prevalence is $72 \%$ in swamp). In a previous study (unpublished data) carried out in 10 watery areas in Loire Atlantique, we observed that $M$. coypus infection rates varied between 0 and $50 \%($ mean $=9 \%$ ) in the different areas but it reached a mean rate of $42 \%$ in $F$. bepatica infected areas. $F$. hepatica carrying seems to be frequent in $M$. coypus and is commonplace in many populations, in several different environments. Relationships between wild fauna and $F$. hepatica are different depending on the species. Some wild small mammals species do not seem to be naturally susceptible to the parasite and may play no role in fasciolasis disease (O. zybethicus).

Other small mammals species are only able to harbour fluke livers in particular environmental conditions (Rattus spp., micromammals) and serve, as the black rat Rattus rattus in Corsica, as a reservoir of fasciolosis in these specific biotopes (Valero et al., 1998) [Mas- 
Coma (1988) measured an infection rate equal to $48.5 \%$ in Corsica Rattus rattus].

Finally, some wild species are frequently natural hosts of $F$. hepatica (O. cuniculus, M. coypus). The epidemiological role of these wild hosts vary depending on the nature of the definitive host and the environment. In fact, O. cuniculus is a favourable host concerning the duration and the intensity of $F$. bepatica infection but seems to be less favourable concerning the pursuit of life parasitic cycle: the number of infected shedding O. cuniculus is generally low (18\% in our study, Table I), fluke eggs eclosability and developmental success are poor (Boray, 1969; Rondelaud \& Dreyfuss, 1995). These results would tend to reduce the impact of O. cuniculus infection in the fasciolosis epidemiology. On the contrary, notwithstanding eclosability and development success of faecal fluke eggs have not been studied yet, high number of infected and shedding M. coypus (fluke eggs shed by $80 \%$ of infected animals) combined with high population density, opportunistic behavior and widespread distribution (Jouventin et al., 1996), suggest that M. coypus probably plays a major epidemiological role in fasciolosis. This role is compounded by the fact that this rodent is amphibious and used to defaecate in water and shed fluke eggs close to habitats of snails which are potential intermediate hosts; a behavior very much to the benefit of the parasite and its life cycle.

These results demonstrate that rodents play a more complex epidemiological role in the fasciolosis epidemiology than that reported by Macko \& Basanda (1977) who thought that rodents were just scattering agents of $F$. bepatica, and increase the interest that veterinary research have to bear on it. The variations of the infestation rate according to the environment also show that its role can be different according to the biotope incriminated.

\section{REFERENCES}

Alcouffe T., Ducos de Lahitte J. \& Ducos de Lahitte N. Étude épidémiologique du parasitisme de l'isard. Revue de Médecine Vétérinaire, 1992, 3, 207-211.

Bailenger J., Tribenley J., Amyot B. \& Duret J. Importance des léporidés comme réservoir sauvage dans l'épidémiologie des distomatoses à $F$. hepatica et $D$. dentriticum. Annales de Parasitologie Humaine et Comparée, 1965, 40, 51-54.

Biadi F. \& Le Gall A. Le lapin de garenne. Vie, gestion et chasse d'un gibier authentique. Hatier Ed., Paris, 1993, 3235.

BARRAS J. Le chevreuil de repeuplement à l'importation, mortalité en cours de transport, bilan parasitaire sur les cadavres. Thèse de Doctorat Vétérinaire, Lyon, France, 1982.
Bollo E., Rossignoli M., Morosino A. \& Schroder C. Patologia dell'infestazione da Fasciola hepatica nel cinghiale. Obiettivi e Documenti Veterinari, 1993, 14 (10), 55-57.

Boray J.C. Experimental fasciolasis in Australia. Advances in Parasitology, 1969, 7, 96-210.

Boulard C., Argente G. \& Hillion E. Comparaison de la détection des foyers de fasciolose par test ELISA sur le lactosérum et le sérum et par coproscopie. Annales de Recherches Vétérinaires, 1985, 16, 363-368.

Boussinesq X., Le Pape P., Ferre J. Y. \& Marjolet M. La fasciolose en Loire-Atlantique. Prévalence de l'affection chez le Ragondin $M$. coypus : premiers résultats. Bulletin de la Société Francaise de Parasitologie, 1986, 4 (1), 39-43.

Delecole J.P. Le Ragondin et la douve. Bull. Soc. Vet. Prat. de France, 1981, 65, 391-392.

Dreyfuss G., Bouteille B., Rondelaud D., Darde M.L. \& Pestre-AleXANDRE M. A propos de quelques observations sur les cas récents de fasciolose humaine dans la région du Limousin. Bulletin de la Société Française de Parasitologie, 1994, 12, 29-34.

HUBARD D. Les mammifères sauvages de la faune française réservoirs d'helminthes pour les ruminants domestiques. Thèse de Doctorat Vétérinaire, Nantes, 1985, 26-32.

Johannsen U., ARnold P., Schuppel K. F., Ribbeck R. \& Haupt W. Fascioliasis in moufflons. Angewandte Parasitologie, 1989, 30 (2), 87-99.

Jouventin P., Micol T., Verheyden C. \& Guedon G. Le ragondin: biologie et méthodes de limitation des populations. Acta Ed., 28-29.

Knapp S.E. \& Presidente P.J. A. Eficacity of rafoxanide against natural Fasciola bepatica infections in cattle. American Journal of veterinary research, 1971, 96, 335.

Mage C., Loisel J. \& Bonnand P. Infection par Fasciola bepatica en élevage laitier. Revue Médicale Vétérinaire, 1989, 140, 929-931.

MaGe C. Conséquences zootechniques de l'infestation naturelle de Fasciola bepatica chez des taurillons limousins. Revue Médicale Vétérinaire, 1990, 141, 205-208.

Mas-Coma S., Fons R., Feliu C., Bargues M.D., Valero M.A. \& Galan Puchades M.T. Smalls mammals as natural definitive host of the liver fluke, Fasciola bepatica Linnaeus, 1758 (Trematoda: Fasciolidae): a review and two new records of epidemiologic interest on the Island of Corsica. Rivista di Parassitologia, 1988, 5 (49), 1, 73-78.

Mas-Coma S., Fons R., Feliu C., Bargues M.D., Valero M.A. \& Galan Puchades M.T. Conséquences des phénomènes liés à l'insularité dans les maladies parasitaires. La grande douve du foie (Fasciola hepatica) et les muridés en Corse. Bulletin de la Société Neuchâteloise de Sciences naturelles, 1989, 110, 57-62.

Mas-Coma S., Bargues M.D. \& Esteban J.G. Human Fasciolosis. In: Fasciolosis. Dalton J.P. Ed., CAB international Publishing, Wallingford, Oxon, UK, 1999, 411-414.

Molan A.L. \& Hussein M.M.S. A general survey of blood and tissue parasites of some rodents in Arbil province, Iraq. Acta Pathologica Microbiologica et Immunologia Scandinavica, 1988, 96 (3), 47-49. 
Nesterov V., Almasan H. \& Scarlatescu J. Fasciola bepatica la animallele salbatice. Revista de Zootehnie si Medicina Veterinara, 1973, 23, 69-75.

OLSEN O.W. Wild rabbits as reservoir hosts of the common liver fluke, Fasciola bepatica, in southern Texas. Journal of Parasitology, 1948, 2, 119-123.

PERRY H.R Jr. Muskrats Ondatra zybethicus et Neofiber allini. In: Wild mammals of North America. John Hopkins univ. Press Ed., 1982, 23-28.

Redington J.J., Leid R.W. \& Wescott R.B. The susceptibility of the goat to Fasciola bepatica infections. Veterinary Parasitology, 1986, 19, 145-150.

Rondelaud D. \& Dreyfuss G. Fasciola bepatica: the influence of the definitive host on the caracteristics of infection in the snail Lymnea truncatula. Parasite, 1995, 2, 275-280.

Rosoux D. Bilan parasitaire du Ragondin. Thèse Vétérinaire, Univ. Liège, 1984, 1-16.

Rubilar C.L. \& Merello E. Endoparasitism in wild rabbits (Oryctolagus cuniculus) in the Florida zone. VIII region, Chile. Agro-Ciencia, 1987, 3 (1), 31-34.

SANTOS I.C.S., Scaini C.J., Rodrigues L.A.F. \& Silva SANTOS I.C. Myocastor coypus as a wild reservoir host of Fasciola hepatica (Lineu, 1758). Revista Brasileira de Parasitologia Veterinaria, 1992, 1 (1), 27-30.

SpITz F. Étude des biotopes de circulation de quelques espèces de micromammifères par la méthode du carré de piégeage. Mammalia, 1965, 29, 390-399.

Terracciano G., Mancianti F. \& Marconcini A. Parasitological investigation in hares. Summa, 1988, 5 (3), 217-220.

Valero M.A., Marcos M.D., Fons R. \& Mas-Coma S. Fasciola bepatica development in the experimentally infected black rat Rattus rattus. Parasitology Research, 1998, 84, 188-194.

ZAKARIEV A.Y.A. The geographical distribution of the helminths of coypus in USSR. Mat. Nauch. Konf. Dag. Filial. Georg. Obs. Soy, 1977.

Reçu le 6 avril 1999 Accepté le 21 mars 2000 